\title{
Carbohydrates in the Honeydew Excreted by Ceroplastes pseudoceriferus (GREEN)
}

\author{
By Yoshio Tamaki: \\ Tea Research Station, Ministry of Agriculture and Forestry, \\ Kanaya, Shizuoka
}

Ceroplastes pseudoceriferus (GREEN), one of the common scale insects infesting tea plant in Japan, excretes a white waxy material and honeydew with a large variety of ninhydrin-positive substances and carbohydrates (TAMAKI, 1963). Amino acids and amides contained in the honeydew and in the tea bark have been elucidated (TАMAKI, 1964).

The present paper deals with the carbohydrate composition of the honeydew excreted by Ceroplastes pseudoceriferus and of its host plant.

\section{MATERIALS AND METHODS}

Adult female insects were collected from twigs of infested tea plants (mainly of clone $\mathrm{Y}-2$ ) in fields of the Tea Research Station from autumn, 1962 to spring, 1963. All the insects were stored in a deep freezer at $-20^{\circ} \mathrm{C}$ until experimental use. The fresh honeydew was collected using a capillary pipette by pressing the dome of wax which was lifted carefully without disturbing the insect body. When a large amount of the honeydew was needed, the insects were shaken lightly with chloroform, and the honeydew was separated as described in the preceding paper (TAMAKI, 1964). Alcoholic extract of tea bark (clone Yabukita and domestic variety) on which the scale insect lives, was also prepared according to the method described by $\mathrm{T}_{\mathrm{A}}$ MAKI (1964). Reducing sugar content in the honeydew was determined by the -Somogyi's colourimetric method (Somogyr, 1952).
One-dimensional ascending paper chromatography on paper sheets of Tôyô-roshi No. 51 (20 cm in length) or Whatman No. 1 (22 cm in length) was carried out with solvent systems as follows: $n$-Butanolacetic acid-water $(4: 1: 2)$ (ToRII \& $\mathrm{KA}^{-}$ NAZAWA, 1954), $n$-butanol-pyridine-water (6:4:3) (JEANS et al., 1951), $n$-butanolethanol-acetone-water (5:4:3:2) (GRAY \& Fraenkel, 1954), ethyl acetate-acetic acidwater (3:1:1) (HACKMAN \& Trikojus, 1952), and phenol-water $(5: 1)$ (ConsDen et al., 1944). Multiple development technique was adopted to gain a good separation of each sugar. For each running, $10 \sim 30 \mu 1$ of the fresh honeydew or the alcoholic extract of tea bark was applied on the paper. In many cases, a mixture of authentic sugars and/or sugar alcohols was co-chromatographed with the honeydew or the tea bark extract.

Sugars and sugar alcohols were detected on papers by spraying with the following colour reagents : 1) $p$-Amino hippuric acidphthalic acid reagent (SATTLER \& Z ERBAN, 1952) for reducing and non-reducing sugars, 2) resorcinol reagent (BRyson \& Mitchell, 1951) for ketoses or oligosaccharides containing ketose, and 3) bromocresol purple reagent (BRADFIELD \& FLOOD, 1950) for sugar alcohols.

Sugars and sugar alcohols in the honeydew and in the alcoholic extract of tea bark were identified by comparing their $R f$ values on papers to those of authentic compounds. Furthermore sugar alcohols in the honeydew were isolated as crystals, and their melting points were determined.

1 Present address: Agricultural Chemicals Inspection Station, Ministry of Agriculture and Forestry, Kodaira, Tokyo.

(Received for. pubfication, February 17, 1964) 


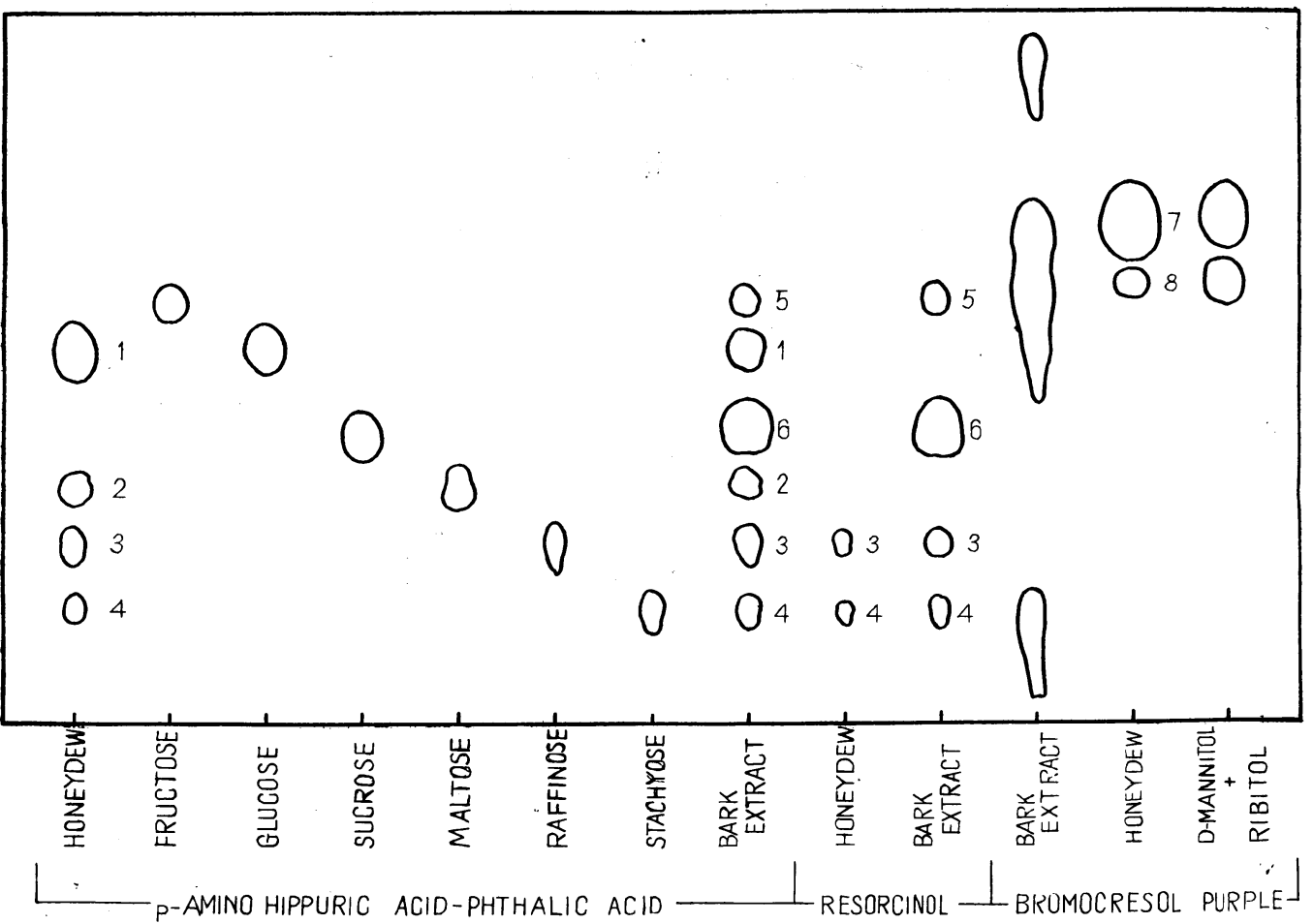

Fig. 1. Reconstructed chromatograms of honeydew, extract of tea bark, and some known carbohydrates. On Whatman No. 1 paper, multiple development (4 times) with the solvent system of $n$-butanol-acetic acid-water $(4: 1: 2)$.

\section{RESULTS}

The reducing sugar content in the honeydew excreted from Ceroplastes pseudoceriferus was 2.8 per cent on dry weight basis.

Reconstructed chromatograms of the honeydew, the alcoholic extract of the tea bark, and some carbohydrates used for comparison in analysis are presented in Figure 1. There was no difference in carbohydrate composition of tea barks between clone Yabukita and domestic variety. In spite of a suggestion by GRAY and Fraenkel (1954) on a hydrolytic effect of acetic acid in a chromatographic solvent, no hydrolytic effect of acetic acid was recorded in the present experiments. On the chromatogram of honeydew run with n-butanol-acetic acid-water, four spots (Nos. 1 4) were detected by spraying with $p$-amino hippuric acid-phthalic acid reagent, and two spots (Nos. 3 and 4 ) were detected by spraying with resorcinol reagent; the latter two were considered to be ketoses or oligosaccharides containing ketose. Spot No. 1 showed the same Rf value and colour tone as authentic glucose. The Rf values of spot Nos. 2, 3, and 4, which were lesser in quantity than the spot No. 1 , well agreed with those of authentic maltose, raffinose, and stachyose, respectively (Figure 1). These results were the same as with the other solvent systems such as $n$-butanol-pyridine-water and $n$ butanol-ethanol-acetone-water.

In the alcoholic extract of the tea bark, six spots were detected by spraying with $p$-amino hippuric acid-phthalic acid reagent, and four spots by resorcinol reagent on the chromatograms run with $n$ butanol-acetic acid-water solvent. The spots Nos. 1, 5 , and 6 on the chromatogram of the alcoholic extract of the tea bark showed the same $\mathrm{Rf}$ values and colour 
tones as those of authentic glucose, fructose, and sucrose, respectively. The $\mathrm{Rf}$ values and colour of the spot Nos. 2, 3, and 4 on the chromatogram of the tea bark extract agreed closely with those of authentic maltose, raffinose, and stachyose, respectively. In order to confirm the presence of maltose, raffinose, and stachyose in the tea bark, a large amount of the alcoholic extract of the tea bark was submitted to a band chromatography with a solvent of $n$-butanol-acetic acid-water. The bands corresponding to spots Nos. 2,3 and 4 were cut off, and then extracted with 50 per cent methanol. Each concentrate of the methanolic solutions was co-chromatographed with the corresponding authentic compounds, with solvent systems of $n$-butanol-pyridine-water, $n$-butanol-ethanol-acetone-water, and phenol-water. As results of these chromatography, the spots Nos. 2,3, and 4 on the chromatogram of the alcoholic extract of the tea bark are confirmed to be maltose, raffinose, and stachyose, respectively.

From colour intensity and size of each spot on chromatograms, content of sugars in the tea bark was assumed to be the following order : sucrose $>$ glucose $>$ fructose $=$ raffinose $>$ maltose $=$ stachyose.

By spraying with bromocresol purple reagent, two spots, one large and the other small, were given on the chromatogram of the honeydew sample, as shown in Figure 1. The large spot ( $\mathrm{Rf}: 0.72$ ) is considered to be ribitol and the small one (Rf : 0.63 ) is D-mannitol. In order to identify more clearly, isolation of the sugar alcohols were undertaken. The honeydew separated from $50 \mathrm{~g}$ of the insects, accord- ing to the previous description (TAMAKI, 1964), was concentrated at a temperature of about $50^{\circ} \mathrm{C}$ under reduced pressure, and then desiccated on silica-gel in vacuo. About $1.4 \mathrm{~g}$ of dry matter of honeydew was obtained from $50 \mathrm{~g}$ of the insects. The dry matter was extracted with about $20 \mathrm{ml}$ of hot ethanol. After cooling the ethanol solution, white needle crystals (Crystal A) precipitated, were obtained by filtration. By further concentration of the mother liquid, another white crystals (Crystal B), which are in much larger amount than Crystal A, were obtained. These crystals were recrystalized from ethanol. Figure 2 shows a picture of Crystal A. The melting points of these crystals and of known D-mannitol and ribitol were

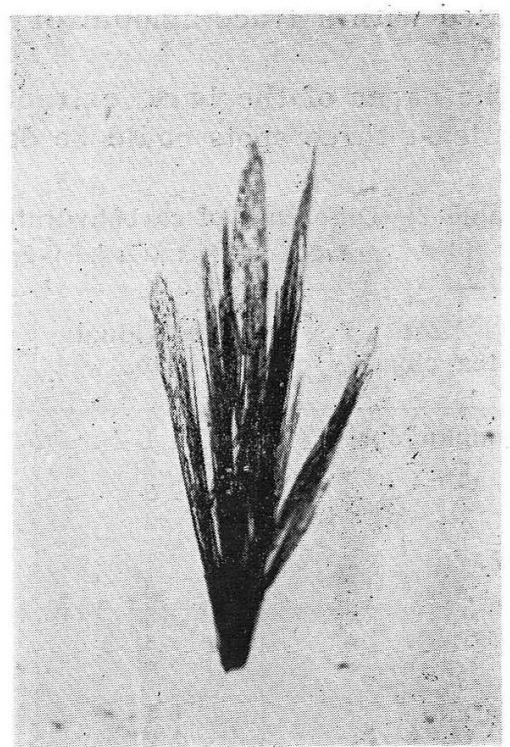

Fig. 2. D-Mannitol (Crystal A) isolated from the honeydew excreted by C. pseudoceriferus (GREEN).

Table 1. Rf values obtained by one-dimensional paper chromatography with Whatman No. 1 paper (22 cm length); each solvent was developed in three times.

\begin{tabular}{l|cccc}
\hline \multicolumn{1}{c|}{ Solvent systems used } & $\begin{array}{c}\text { Authentic } \\
\text { ribitol }\end{array}$ & Crystal B & $\begin{array}{c}\text { Authentic } \\
\text { D-mannitol Crystal A }\end{array}$ \\
\hline n-Butanol-pyridine-water $(6: 4: 3)$ & 0.69 & 0.70 & 0.60 & 0.61 \\
n-Butanol-acetic acid-water $(4: 1: 2)$ & 0.59 & 0.60 & 0.54 & 0.54 \\
n-Butanol-ethanol-acetone-water $(5: 4: 3: 2)$ & 0.64 & 0.64 & 0.55 & 0.55 \\
Ethyl acetate-acetic acid-water $(3: 1: 1)$ & 0.64 & 0.65 & 0.58 & 0.58
\end{tabular}


determined with following results :

Crystal A : $163.0 \sim 164.0^{\circ} \mathrm{C}$

Crystal B : $99.5 \sim 101.5^{\circ} \mathrm{C}$

D-Mannitol (Koso Chemical Co., Japan)

$$
\text { : } 163.0 \sim 164.0^{\circ} \mathrm{C}
$$

Ribitol (Wakô Pure Chemical Ind., Japan) : $101.0 \sim 102.0^{\circ} \mathrm{C}$

Crystal A and Crystal B were submitted to one-dimensional ascending chromatography on Whatman No. 1 papers with $n$-butanol-acetic acid-water, $n$-butanol-pyridine-water, $n$-butanol-ethanol-acetone-water, and ethyl acetate-acetic acid-water as solvents. All the Rf values of Crystal A and Crystal $B$ in these solvent systems agreed closely with those obtained with authentic D-mannitol and ribitol, respectively (Table 1 ). Crystal $B$ was still contaminated with a trace amount of D-mannitol.

On the paper of the bark extract sample, at least three spots could be detected by spraying with bromocresol purple reagent. One of these spots, however, seemed to be consisted of two or three spots (Figure 1).

In order to ascertain whether or not ribitol is contained in the tea bark, about $2 \mathrm{ml}$ of the alcoholic extract of the tea bark was submitted to a band chromatography with $n$-butanol-acetic acid-water as solvent. Ribitol area located on the paper sheet was cut off, and extracted with 50 per cent methanol. The methanol solution was concentrated, and was submitted to two-dimensional paper chromatography on Tôyô-roshi No. 51 paper $(20 \times 20 \mathrm{~cm})$, with the authentic ribitol for comparison. nButanol-acetic acid-water and ethyl acetateacetic acid--water were used as running solvents. By this method, ribitol spot could be separated well from fructose spot, and presence of ribitol was confirmed in the tea bark. The content of ribitol in

Table 2. Difference of carbohydrate composition in the honeydew excreted by Ceroplastes pseudoceriferus (GREEN) growing on several clones of tea plant.

\begin{tabular}{|c|c|c|c|c|c|c|}
\hline \multirow{2}{*}{$\begin{array}{l}\text { Host } \\
\text { tea clones }\end{array}$} & \multirow{2}{*}{$\begin{array}{c}\text { Individual } \\
\text { No. }\end{array}$} & \multicolumn{5}{|c|}{ Carbohydrates detected } \\
\hline & & Ribitol & Glucose & Maltose & Raffinose & Stachyose \\
\hline Sayamamidori & $\begin{array}{l}1 \\
2 \\
3 \\
4\end{array}$ & $\begin{array}{l}+ \\
+ \\
+ \\
+\end{array}$ & + & & & \\
\hline C -7 & $\begin{array}{l}1 \\
2 \\
3 \\
4 \\
5\end{array}$ & $\begin{array}{l}+ \\
+ \\
+ \\
+ \\
+\end{array}$ & $\begin{array}{l}+ \\
+\end{array}$ & & & \\
\hline Yabukita & $\begin{array}{l}1 \\
2 \\
3 \\
4\end{array}$ & $\begin{array}{l}+ \\
+ \\
+ \\
+\end{array}$ & $\begin{array}{l}+ \\
+ \\
+ \\
+\end{array}$ & $\begin{array}{l}+ \\
+ \\
+ \\
+\end{array}$ & $\begin{array}{l}+ \\
+\end{array}$ & $\begin{array}{l}+ \\
+ \\
+ \\
+\end{array}$ \\
\hline $\mathrm{Y}-2$ & $\begin{array}{l}1 \\
2 \\
3 \\
4 \\
5\end{array}$ & $\begin{array}{l}+ \\
+ \\
+ \\
+ \\
+\end{array}$ & $\begin{array}{l}+ \\
+ \\
+ \\
+ \\
+\end{array}$ & $\begin{array}{l}+ \\
+ \\
+ \\
+ \\
+\end{array}$ & $\begin{array}{l}+ \\
+ \\
+ \\
+ \\
+\end{array}$ & $\begin{array}{l}+ \\
+ \\
+ \\
+ \\
+\end{array}$ \\
\hline Benihomare & $\begin{array}{l}1 \\
2 \\
3 \\
4 \\
5\end{array}$ & $\begin{array}{l}+ \\
+ \\
+ \\
+ \\
+\end{array}$ & $\begin{array}{l}+ \\
+ \\
+ \\
+\end{array}$ & $\begin{array}{l}+ \\
+ \\
+\end{array}$ & $\begin{array}{l}+ \\
+ \\
+ \\
+\end{array}$ & \\
\hline Domestic variety & $\begin{array}{l}1 \\
2 \\
3 \\
4\end{array}$ & $\begin{array}{l}+ \\
+ \\
+ \\
+\end{array}$ & $\begin{array}{l}+ \\
+ \\
+ \\
+\end{array}$ & & + & \\
\hline
\end{tabular}


the tea bark seemed to be smaller than that of other accompanying sugars. The presence of $\mathrm{D}$-mannitol in the tea bark could not be confirmed by this method, because the mannitol spot did not separate from fructose and both fructose and mannitol show same colour by spraying with bromocresol purple reagent.

Comparison of carbohydrate composition of the honeydews excreted by the scale insects growing on different clones of tea plants, was done by means of the paper chromatography. The results obtained are given in Table 2. Carbohydrate composition of the honeydew excreted by the scale insects somewhat differed with clones of tea plants on which the insect fed. In the honeydew collected from the insects on Sayamamidori and $\mathrm{C}-7$, anyone of oligosaccharides could not be detected. On the other hand, some oligosaccharides were detected in honeydew from individuals on clone Yabukita, Y-2, and so on. Ribitol occurred in all of the honeydews examined, whereas D-mannitol was not examined in these experiments.

\section{DISCUSSION}

Glucose, maltose, raffinose, and stachyose were detected in the honeydew excreted by Ceroplastes pseudoceriferus on tea twigs. These sugars were also detected in alcoholic extract of the tea bark. It is resonable to believe that these four sugars contained in honeydew are derived from the insect's food. Fructose and sucrose were found in the tea bark, but not in the honeydew; these two sugars are assumed to be utilized completely by the insect.

The carbohydrate composition of honeydews excreted by aphids and coccids, and of their hosts, has been examined by several workers, and their results are given in Table 3. By referring these worker's results, with an exception of Tuberolachnus salignus reported by MitTler (1958), almost all monosaccharides and disaccharides found in the honeydews seem to be also contained in their host plants. In case of oligosaccharides, however, the carbohydrate composition of honeydews excreted by insects somewhat differs from that of host plants. Glucosucrose (4 G-alpha-glucosylsucrose) and sometimes its higher homologuses, which are never found in their host plants have been detected in the honeydews of Eucallipterus tiliae and Eulecanium coryli by BAcon and Dickinson (1957), Pseudococcus citri by GRAY and Fraenkel $(1953,1954)$, Coccus hesperidum by Wolf and Ewart (1955), Prociphilus tessellatus by STEPhen (1959), and probably in Planococcus citri, Coccus pseudomagnoliarum and Saisselia oleae by EwART and Metcalf (1956). Furthermore, a particular oligosaccharide, melezitose ( $3 \mathrm{~F}$-alpha-glucosylsucrose) occurred in the honeydews excreted by Icerya purchasi, Eucallipterus tiliae, and Tuberolachnus salignus, but not in their hosts (Ewart \& Metcalf, 1956; Bacon \& Dickinson, 1957; Mittler, 1958).

As has been suggested by Gray and Fraenkel (1954) and by Ewart and Metcalf (1956), glucosucrose and melezitose should be synthesized by the insects. In case of Ceroplastes pseudoceriferus, however, these sugars could not be detected in the honeydew.

Two sugar alcohols were isolated from the honeydew excreted by Ceroplastes pseudoceriferus, and identified to be ribitol and D-mannitol. Ribitol was also found in the tea bark, while D-mannitol was not confirmed to be present in it. So far as ribitol is concerned, it is possible to assume that the scale insect ingests the sugar alcohol from host plant and excretes it without any change. But the possibility of the biosynthesis of ribitol in the insect and of some important role of the sugar alcohol in the physiology of the scale insect cannot be dismissed. HACKMAN and Trikojus (1952) reported that ribitol is contained as only sugar alcohol in the honeydew excreted by $C$. destructor, $C$. ceriferus and $C$. rubens, and in their hosts. They believed that these three species of the scale insects ingest ribitol and excrete it as unchanged form. 


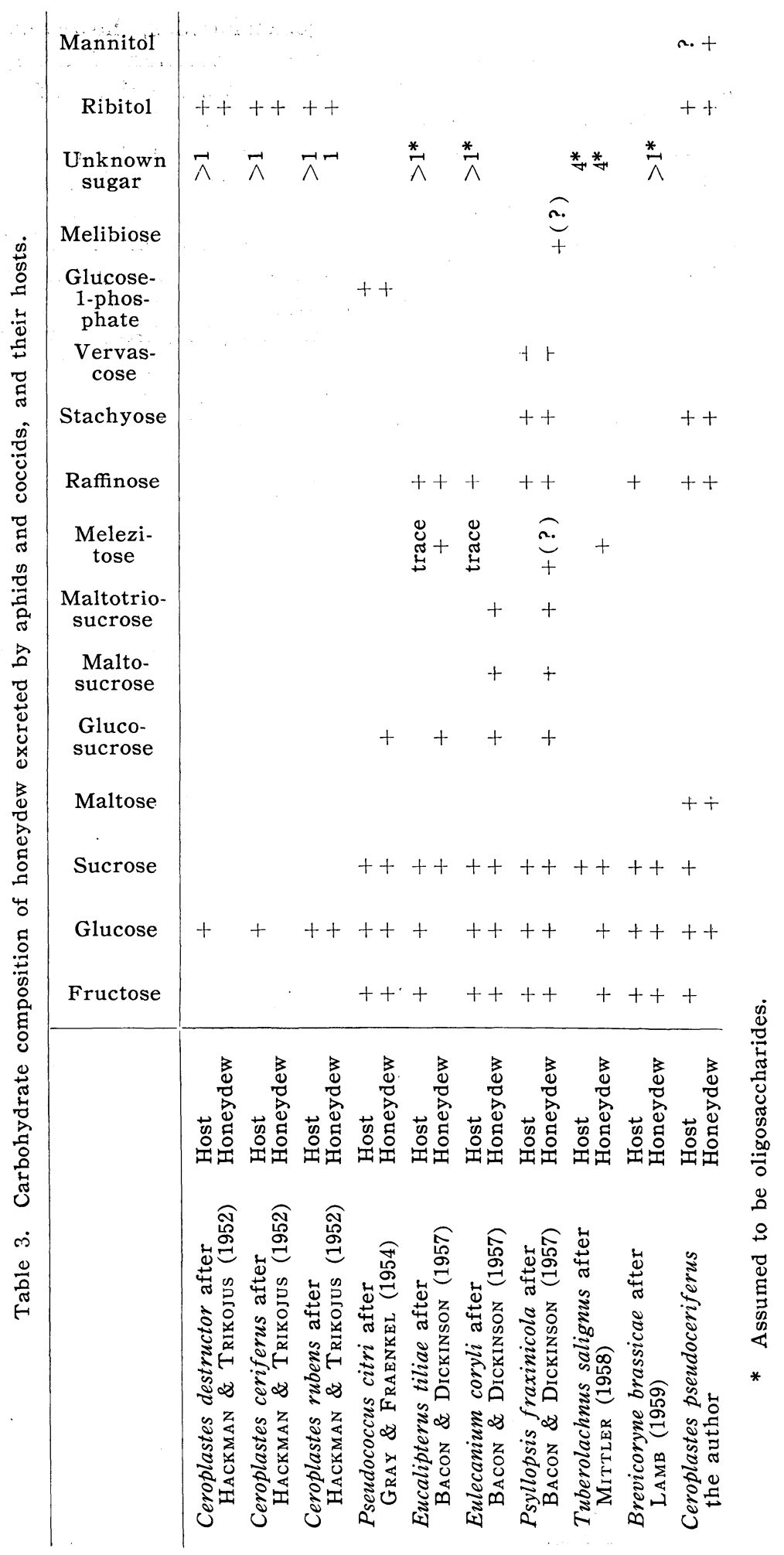


By referring the colour intensity and size of spots on the paper chromatograms, it is interesting to note that the content of ribitol in the tea bark is smaller than that of other carbohydrates, while that in the honeydew excreted by the insect is much larger than the other carbohydrates. From the results, it is considered that this insect can utilize sucrose, fructose, glucose, and maltose at higher efficiency, but not utilize ribitol.

Reducing sugar content in honeydews excreted by Myzus circumflexus growing on Katahdin potato (Maltais \& Auclair, 1952) and by Brevicoryne brassicae growing on swedes (LAMB, 1959) was 35.7 per cent and $24 \pm 0.65$ per cent on dry weight basis, respectively. Invert sugar content of honeydews excreted by Drepanosiphum platanoides and Pemphigus sp. was 24.75 and 24.5 per cent, respectively (BusGen, 1891; Тотн, 1933, 1937). On the contrary, the reducing sugar content of the honeydew excreted by Ceroplastes pseudoceriferus was only 2.8 per cent on dry weight basis. This value of the reducing sugar content is obviously smaller than those of above mentioned aphids. These aphids do not excrete so much wax-like substances as the genus Ceroplastes does. From these considerations it is reasonable to suggest that Ceroplastes pseudoceriferus utilizes highly the carbohydrates from its host plant juice for the biosynthesis of wax in the covering dome.

\section{SUMMARY}

Carbohydrate composition of the honeydew excreted by Ceroplastes pseudoceriferus (GREeN) and of tea twigs on which the the scale insects live, were analyzed by paper chromatography.

In the honeydew, glucose, maltose, raffinose, stachyose, ribitol, and D-mannitol were detected. Ribitol and D-mannitol were isolated as crystals from the honeydew. Carbohydrate composition of the honeydew varies with clones of tea plant on which the insects live.
In the tea bark, fructose, glucose, sucrose, maltose, raffinose, stachyose, and ribitol were detected. The relative amount of these carbohydrates was assumed to be in the following order: sucrose $>$ glucose> fructose $=$ raffinose $>$ maltose $=$ stachyose $>$ ribitol. The presence of D-mannitol could not be confirmed in the tea bark.

From these results obtained it was suggested that Ceroplastes pseudoceriferus (GREEN) living on tea twigs mainly utilizes fructose and sucrose contained in their food. It is possible to assume that ribitol ingested by the scale insect was excreted without any change.

The fact that the reducing sugars content of the honeydew of the scale insect is remarkably smaller than that of aphids, seems to indicate that waxy substances of the scale insect would mainly be originated from the reducing sugars in the tea plant.

\section{ACKNOWLEDGEMENTS}

The author indebted to $\mathrm{Mr}$. T. KaneKo and Dr. H. ToRII of the Tea Research Station for their constant interest and helpful suggestions. He also expresses his deep gratitude to Dr. S. IsHin of Kyoto University and Dr. C. Hirano of the National Institute of Agricultural Sciences for their unfailing guidance and encouragement throughout the course of this work.

\section{REFERENCES}

BACon, J. S. D. \& B. Dickinson (1957) Biochem. J. 66: $289 \sim 297$.

Bradfield, A. E. \& A. E. Flood (1950) Nature 166: $264 \sim 265$.

Bryson, J. L. \& T. J. Mitchell (1951) Nature 167: 864 .

Busgen, M. (1891) Biol. Zentr. 11: 193 200.

Consden, R., A. H. Gordon, \& A. J. P. Martin (1944) Biochem. J. 38: 224 232.

Ewart, W. H. \& R. L. Metcalf (1956) Ann. Ent. Soc. Amer. 49: 441 447.

Gray, H. E. \& G. FraenKel (1953) Science 118: $304 \sim 305$.

Gray, H. E. \& G. Fraenkel (1954) Physiol. Zool. 27: $56 \sim 65$.

Hackman, R. H. \& V. M. Trikojus (1952) Biochem. J. 51: $653 \sim 656$. 
Jeans, A., C. S. Wise \& R. J. Dimler (1951) Anal. Chem. 23: $415 \sim 420$.

LAMB, K. P. (1959) J. Ins. Physiol. 3: 1 13.

Maltais, J. B. \& J. L. Auclair (1952) Canad. J. Zool. 30: 191 193 .

MitTler, T. E. (1958) J. Exptl. Biol. 35: 74 84.

Sattler, L. \& F. W. Zerban (1952) Anal. Chem. 24: 1862 .

Soмоgyi, M. (1952) J. Biol. Chem. 195: 19 23.

Stephen, W. A. (1959) J. Econ. Ent. 52: 353.

TAMAki, Y. (1963) Jap. J. Appl. Ent. Zool. 7: 355 357.
Tамакі, Y. (1964) Jap. J. Appl. Ent. Zool. 8: 159 164.

Toril, H. \& J. Kanazawa (1954) Study of Tea (Japan) 10: $44 \sim 48$.

Тотн, L. (1933) Z. Morphol. Oekol. Tiere 27: $692 \sim 731$.

Тотн, L. (1937) Z. Morphol. Oekol. Tiere 33: $412 \sim 437$.

Wolf, J. P. III \& W. H. EWART (1955) Arch. Biochem. Biophys. 58: 365 372.

\section{摘要}

ツノロウムシが分泌する honeydew 中の炭水化物について

\section{玉 木 佳 男 \\ 農林省茶業試験場}

茶樹に寄生するツノロウムシ，Ceroplastes pseudoceriferus（GREEN）の虫体被覆物中にとりこまれている honeydew 中の炭水化物構成をペーパークロマトグラ フィーによって定性的に調べ，茶樹樹皮中に見られるそ れらと比較検討した。

honeydew 中の炭水化物としてはグルコース，マル トース, スタキオース, リビトール，およびマンニトー ルを検出し，このうち糖アルコールであるリビトールと マンニトールは結晶として分離同定した。 honeydew 中のこれら炭水化物は茶樹の系統によって検出される程 度が異なり，6 種の茶樹系統から採集したッノロウムシ 27 個体について 調べたところこれらの検出ひん度は, リビトール>グルコース>マルトース =ラフィノース> スタキオースの順であった。

茶樹樹皮中から注 7 種の炭水化物を検出しそれらの相 対的な濃度は, シュクロース>グルコース>フラクトー
ス=ラフィノース $>$ マルトース $=$ スタキオース $>$ リビト 一ルの順であると考えられた。

これらの結果からッノロウムシは食物中のフラクトー ス拉よびシュクロースをほとえど完全に利用しており， またその他の糖もある程度利用していると考元られる。 糖アルコールについては, リビトールに関する限り，こ の虫は食物中のリビトールをそのままの形で排泄してい るのではないかと考えられる。

Honeydew 中の還元糖を SoMOGYI の比色法で定量 したところ，乾物当り $2.8 \%$ であり，この值はアブラ ムシ類の honeydew について調べられている值と比し て約 $1 / 10$ であった。この事実はツノロウムシが大量の ろう質物を分泌する事実と考え合せると，ツノロウムシ のろう質物が，食物中の糖類から由来しているのではな いかとの考えを起こさしめる。 